\title{
Technologie, mij(')n zorg!
}

Citation for published version (APA):

de Witte, L. P. (2008). Technologie, mij(')n zorg! over langdurende zorg, technologie en innovatie. Maastricht University. https://doi.org/10.26481/spe.20080620lw

Document status and date:

Published: 20/06/2008

DOI:

$10.26481 /$ spe.20080620lw

Document Version:

Publisher's PDF, also known as Version of record

\section{Please check the document version of this publication:}

- A submitted manuscript is the version of the article upon submission and before peer-review. There can be important differences between the submitted version and the official published version of record.

People interested in the research are advised to contact the author for the final version of the publication, or visit the DOI to the publisher's website.

- The final author version and the galley proof are versions of the publication after peer review.

- The final published version features the final layout of the paper including the volume, issue and page numbers.

Link to publication

\footnotetext{
General rights rights.

- You may freely distribute the URL identifying the publication in the public portal. please follow below link for the End User Agreement:

www.umlib.nl/taverne-license

Take down policy

If you believe that this document breaches copyright please contact us at:

repository@maastrichtuniversity.nl

providing details and we will investigate your claim.
}

Copyright and moral rights for the publications made accessible in the public portal are retained by the authors and/or other copyright owners and it is a condition of accessing publications that users recognise and abide by the legal requirements associated with these

- Users may download and print one copy of any publication from the public portal for the purpose of private study or research.

- You may not further distribute the material or use it for any profit-making activity or commercial gain

If the publication is distributed under the terms of Article $25 \mathrm{fa}$ of the Dutch Copyright Act, indicated by the "Taverne" license above, 


\section{Technologie, mij(')n zorg!}

Over langdurende zorg, technologie en innovatie

\section{Rede}

In verkorte vorm uitgesproken bij de aanvaarding van het ambt van bijzonder hoogleraar Technologie in de Zorg aan de Faculty of Health, Medicine and Life Sciences van de Universiteit Maastricht

op vrijdag 20 juni 2008

door

Prof.dr. Luc P. de Witte

MAASTRICHT UNIVERSITY 
Mijnheer de rector magnificus, waarde collega's, familie, vrienden en vriendinnen, dames en heren,

Technologie, .... mij een zorg.... . Die uitspraak geeft de houding weer die veel professionals in de praktijk van de langdurende zorg hebben ten opzichte van het onderwerp van mijn leerstoel. Die houding is meestal onverschillig, soms sceptisch. Niet zelden staan professionals afwijzend tegenover de inzet van technologie in de zorg. In de curatieve gezondheidszorg, zeg maar het ziekenhuis, is technologie vertrouwd, maar in de langdurende zorg is dat niet zo. Technologie wordt hier vaak gezien als iets dat niet past bij de basisbeginselen van zorg, iets dat strij dig is met de menselijke kant ervan. Dat is vreemd als je bedenkt hoezeer technologie in ons dagelijks leven is doorgedrongen en hoe slecht wij nog zonder die technologie kunnen. Kunt u zich nog een leven voorstellen zonder mobiele telefoon, internet of de tom-tom om de weg te wijzen? In de praktijk van de langdurende zorg gebruiken we dergelijke technologieën nauwelijks. Dat is waarom Technologie mij een zorg! is. De centrale vraag voor mijn leerstoel, en tevens voor mijn lectoraat aan de hogeschool Zuyd, is hoe we technologie op een verstandige manier in kunnen zetten voor de kwaliteit, effectiviteit en efficiëntie van de zorg. Ik richt mij daarbij op de langdurende zorg. Dat is de zorg voor ouderen met beperkingen, de gehandicaptenzorg en de zorg voor mensen met een chronische ziekte.

Die centrale vraag is erg belangrijk omdat juist in deze zorgsectoren enorme uitdagingen liggen. Het is inmiddels wel algemeen bekend dat de zorgvraag in de komende 10-20 jaar sterk zal stijgen, terwijl we tegelijk te maken hebben met een relatief afnemend aantal mensen dat in de zorg zal werken. Om u zonder veel cijfers een beeld te vormen: als we in 2025 de zorg willen leveren op de manier waarop we dat nu doen, dan zou $20 \%$ van de beroepsbevolking in de zorg moeten werken ${ }^{1}$. Op dit moment werkt ongeveer $15 \%$ in de sectoren gezondheid en welzijn, waarvan dus maar een deel in de sector waar ik het nu over heb ${ }^{2}$. In misschien sprekender cijfers: al over $3 \mathrm{j}$ aar zullen er in ons land naar verwachting meer dan 22.000 vacatures voor verzorgenden niveau 3 zij n, hoofdzakelijk in verpleeg- en verzorgingshuizen ${ }^{3}{ }^{4}$. Ik hoef $\mathrm{u}$ niet uit te leggen dat een zo sterke groei onmogelijk is. We zullen het dus anders moeten gaan doen, we zullen de zorg anders moeten organiseren. Technologie biedt daarbij goede mogelijkheden, als we die tenminste slim en verstandig inzetten. Technologie biedt ook bedreigingen. Die zullen we met beleid het hoofd moeten bieden. Ik ben er stellig van overtuigd dat, als ik over 20-30 jaar afhankelijk ben van zorg, die zorg in hoge mate op technologie gebaseerd zal zijn. De zorgprofessional zal veel meer op afstand aanwezig zijn en de rol hebben van adviseur en ondersteuner, met wellicht af en toe een intensiever contact. De contacten zullen vooral via internet of een verbeterde opvolger daarvan plaats vinden. Dat is de derde mogelijke betekenis van de titel van deze rede: Technologie, mijn zorg.

Ik zeg dit niet omdat ik in science fiction geloof, maar omdat het naar mijn overtuiging niet anders kan en omdat de technologie het mogelijk zal maken.

\footnotetext{
${ }^{1}$ SST rapport 66: Zorgtechnologie, kansen voor innovatie en gebruik (2002).

2 www.cbs. nl.

3 Windt, W van der e.a. Regiomarge 2007, de arbeidsmarkt van verpleegkundigen, verzorgenden en sociaalagogen 2007-2011. Prismant, Utrecht, augustus 2007.

${ }^{4}$ Kwartel, A van der e.a. Arbeid in Zorg en Welzij n, stand van zaken en vooruitblik voor de sector zorg en de sector welzijn en maatschappelijke dienstverlening, jeugdzorg en kinderopvang 2007. Prismant, Utrecht, december 2007.
} 
Zo, nu weet $u$ waar ik mij mee bezig houd en waarom het belangrijk is dat er een leerstoel is op dit onderwerp. We kunnen dus eigenlijk aan de borrel, maar zo gemakkelijk komt u er niet vanaf, en ik ook niet. Ik wil u eerst aan de hand van een aantal voorbeelden een concreter beeld geven van waar het om gaat, en ik wil een aantal onderwerpen behandelen die van belang zijn bij het ontwikkelen en implementeren van verstandige toepassingen van technologie in de zorg. Achtereenvolgens behandel ik de volgende onderwerpen: 1) Ik bespreek een aantal trends in de langdurende zorg die richting moeten geven aan de technologische ontwikkelingen; 2) lk ga in op innovatie in de zorg en specifiek op innovatie met behulp van technologie; 3) Ik wil iets zeggen over het belang van samenwerking tussen universiteiten en het hbo, niet vreemd voor iemand die zowel lector als hoogleraar is; 4) Ik wil iets zeggen over het belang van verspreiding en implementatie van kennis en de rol die niet-universitaire kennisinstituten daarbij hebben of zouden moeten hebben; 5) Tenslotte geef ik u inzicht in de concrete plannen die ik heb voor de toekomst, vanuit de drie rollen die ik vervul: die van hoogleraar aan deze universiteit, die van lector aan de hogeschool Zuyd en die van manager onderzoek en ontwikkeling van Vilans, het landelijk kennisinstituut voor de langdurende zorg. Daarna mag u aan de borrel.

\footnotetext{
Voorbeeld 1: de inzet van robots in de ouderenzorg De technologische ontwikkelingen op het terrein van de robotica zijn indrukwekkend. Bekend zijn de op mensen lijkende robots die mensachtige handelingen nabootsen ${ }^{5}$. Maar dat is een eenzij dig beeld. Robotica gaat om veel meer. Een robot is een technisch systeem dat, op geleide van signalen van een of andere sensor, automatisch handelingen verricht. Het simpelste voorbeeld is de deur die automatisch opengaat als je in de buurt komt, maar meestal gaat het om complexere zaken. In industriële sectoren en in beperkte mate ook in de curatieve geneeskunde worden robots in verschillende soorten en maten toegepast. Ze nemen mensen veel werk uit handen en werken met grote precisie en eindeloos geduld aan soms complexe taken. En daarbij maken ze nauwelijks fouten. In de zorg worden ze niet of nauwelijks toegepast. Toch zijn er zeer veel belovende toepassingen denkbaar en met sommige daarvan wordt geëxperimenteerd. Voorbeelden zijn 'speelrobots' voor dementerende ouderen (b.v. Paro ${ }^{6}$ of Aibo ${ }^{78}$ ), de I-Cat ${ }^{9}$ als bedieningsinterface, servicerobots die zelfstandig dingen kunnen vervoeren, soms voorzien van een camera met beeldverbinding naar een zorgcentrale ${ }^{10}$, of geautomatiseerde vervoerssystemen die zelfstandig mensen kunnen verplaatsen ${ }^{11}$. Een ander voorbeeld is het door de J apanner Sankai
}

\footnotetext{
${ }^{5}$ Bijvoorbeeld de Actroid DER: zie http:// www. kokoro-dreams. co.jp/ english/index.html

6 Zie www.paro.jp.

${ }^{7}$ Aibo is een mechanisch robot hondje, geproduceerd door Sony. Zie http:// support. sonyeurope.com/aibo.

${ }^{8}$ Banks M, Willoughby L, Banks W. Animal-assisted therapy and loneliness in nursing homes: use of robotic versus living dogs. J of the American Med Directors Ass 2008; 9(3): 173-177.

${ }^{9}$ De I-CAT is een kattenkort die dienst doet als spraakinterface voor multimedia en omgevingsbesturing, ontwikkeld door Philips.

10 Bij voorbeeld Aethon's Tug robot (www. aethon. com) of de RP-7

(www. intouchhealth.com/ products_rp7robot.html).

${ }_{11}$ Een mooi voorbeeld hiervan is het door de EU gesubsidieerde project MOVEMENT, waarin Vilans participant is. Zie: www. is. tuwien. ac. at/ fortec/ reha.e/ projects/ movement.
} 
ontwikkelde exoskelet voor mensen met een dwarslaesie (de HAL robot ${ }^{12}$ ), of de RI-MAN robot, bedoeld voor het tillen van mensen ${ }^{13}$.

Als ik het over de introductie van dergelijke technologie in de ouderenzorg heb, wordt door de meeste mensen wat lacherig gereageerd. Maar is het zo vreemd gedacht? Waarom zou vervoer van mensen in een verpleeghuis niet via geautomatiseerde systemen kunnen? En is een robot die een oudere tilt slechter dan een tillift met allerlei banden waarin iemand opgetakeld wordt? Het is nog een onwennig beeld, maar wat is er op tegen?

Ik ben van plan de komende jaren serieus onderzoek te ontwikkelen naar de mogelijkheden en onmogelijkheden van robotica in de zorg. Vraagstellingen daarbij hebben betrekking op het identificeren van de meest kansrijke toepassingen, de gebruikseisen, de gebruikservaringen, de acceptatie van deze technologie door cliënten en professionals, ethische aspecten, de effecten op zelfredzaamheid, welbevinden en zorggebruik, en de kosten-effectiviteit.

Een aansprekend voorbeeld van robottechnologie voor mensen met ernstige beperkingen is de ARM manipulator, een robotarm die op een elektrische rolstoel gemonteerd wordt, en die mensen met zeer ernstige beperkingen in de arm-hand functie kan ondersteunen bij het uitvoeren van praktische handelingen. Dit is een van de weinige robottoepassingen t.b.v. de langdurende zorg waarvan de kosteneffectiviteit voor een omschreven doelgroep is onderzocht en aangetoond, en die op grond daarvan in Nederland verstrekt kan worden ${ }^{14}{ }^{15}$. Behalve de ARM manipulator is er geen onderzoek naar de effecten van zorggerelateerde robots gedaan.

\section{Trends in de langdurende zorg}

De Nederlandse gezondheidszorg is complex. Wie niet goed ingevoerd is kan eenvoudig het overzicht verliezen. Er is een grote veelheid aan professionals, verschillende zorgaanbieders, sectoren en deelsectoren, die met behulp van een minstens zo groot aantal wetten, regels en instanties gereguleerd wordt. Inzicht in die complexiteit is belangrijk om te begrijpen waarom innovaties, dus ook innovaties waarbij technologie een rol speelt, in de gezondheidszorg niet altijd eenvoudig verlopen. Daarover later meer. De zorg is niet alleen complex, maar ook sterk in beweging. Onder invloed van demografische ontwikkelingen en veranderende visies op zorg zijn er grote veranderingen gaande. Een paar van die veranderingen op het terrein van de langdurende zorg wil ik nu bespreken.

De eerste en misschien wel meest indringende verandering heb ik zojuist al genoemd: de toenemende zorgbehoefte, in combinatie met een te verwachten tekort aan arbeidskrachten voor de zorg. Het RIVM (Rijksinstituut voor Volksgezondheid en Milieu) schat dat het aantal mensen met een chronische ziekte in de periode 2000-2020 met 35\%zal stijgen en dat in 2015 de helft van de

\footnotetext{
12 HAL robot. Zie: http:// www. cyberdyne.jp/ english/index. html.

13 Zie: www. bmc.riken.jp/ RI-MAN/ index_us. html.

${ }^{14}$ Witte LP de, Gelderblom GJ, Soest K van, e.a. MANUS, een helpende hand. Een verkennende studie naar doelgroepen, indicatiecriteria, gebruik en aspecten van kosteneffectiviteit van de MANUS robotmanipulator. iRv, Hoensbroek, 2000 (in opdracht van CvZ).

${ }^{15}$ Gelderblom GJ, Willen A, Cremers G, Witte LP de. Manus \& Co; een onderzoek naar voorwaarden voor doelmatige verstrekking van een robotmanipulator. iRv, Hoensbroek, 2004 (in opdracht van CvZ).
} 
bevolking van 25 tot 85 jaar een chronische ziekte zal hebben ${ }^{16}$. Ik neem een ziektebeeld als voorbeeld: dementie. Het aantal mensen met dementie bedraagt op dit moment ruim 175.000. De gezondheidsraad raamt dat dit aantal binnen een paar jaar zal zijn opgelopen tot boven de 200.000 en in 2050 tot meer dan 400.000 17. Dit zijn indrukwekkende cijfers. Voor dergelijke aantallen is geen plaats in de intramurale zorg. Het is dus onvermijdelijk dat deze mensen zelfstandig of met mantelzorg in hun eigen woonomgeving zullen moeten blijven, overigens iets wat veel mensen ook willen. Maar daarvoor is wel ondersteuning nodig. Dezelfde trend doet zich bij andere doelgroepen voor. Dit dwingt tot andere zorgvormen.

Het zijn niet alleen de groeiende aantallen die tot nieuwe zorgvormen aanzetten. Ook onze wensen en opvattingen ten aanzien van zorg zijn sterk veranderd. Al langere tijd is er in de gehandicaptenzorg en in de ouderenzorg een tendens naar extramularisering en kleinschaligheid zichtbaar. Dat is de tweede trend die hier van belang is. Het beeld van de grote zorginstelling is aan het verdwijnen en maakt plaats voor kleine woonvormen, begeleid zelfstandig wonen of geheel zelfstandig wonen met technologische ondersteuning en toezicht op afstand. Ook deze trend maakt het noodzakelijk na te denken over nieuwe zorgvormen, waarbij professionals meer op afstand komen.

Zorg zal dus steeds meer thuis in de eigen leefomgeving plaats vinden. Deels omdat het niet anders kan, deels omdat we het graag willen. Hiervoor is technologie nodig die zorg op afstand mogelijk maakt.

Een derde trend in de zorg is dat cliënten in toenemende mate zelf de regie en controle over hun leven en de zorg die ze ontvangen willen hebben. In de zorg voor mensen met een chronische ziekte, maar ook in de gehandicaptenzorg en de ouderenzorg worden de concepten 'eigen regie' en 'zelfmanagement' steeds belangrijker. Cliënten willen niet langer zondermeer aannemen wat de zorgprofessional zegt, maar willen zelf verantwoordelijkheid nemen, zelf kiezen, zelf handelen. Er zijn ook aanwijzingen dat therapieën gebaseerd op zelfmanagement en eigen verantwoordelijkheid effectiever zijn. In ieder geval is de zogenaamde compliance of therapietrouw groter. Deze trend vraagt om een andere organisatie van de zorg en het is belangrijk dat cliënten informatie krijgen over hun eigen situatie, zodat ze ook zelf kúnnen kiezen en handelen. Eenvoudige voorbeelden zijn de diabetespatiënt die op basis van zijn zelf gemeten bloedsuikerwaardes bepaalt hoeveel insuline hij spuit en hoeveel hij eet, en de astmapatiënt die op geleide van de uitkomsten van een eenvoudige spirometer de dosering van zijn medicatie regelt. Daar is echt geen dokter of verpleegkundige voor nodig. Deze trend naar meer eigen regie en zelfmanagement zal zeker verder doorzetten, net als bij zorg op afstand enerzijds vanwege de toenemende aantallen en anderzijds omdat we dit liever zo willen, en omdat het effectief is.

Een vierde trend heeft te maken met de organisatie van zorg. Afstemming en coördinatie van zorg wordt steeds belangrijker, omdat de ontvanger van zorg dat eist en omdat problematiek complexer wordt. Het is bekend dat mensen vaak meerdere chronische ziektes krijgen (comorbiditeit of multimorbiditeit) en in de gehandicaptenzorg is er, onder andere als gevolg van veroudering, een toenemend

16 RIVM. Volksgezondheid Toekomst Verkenning 2006.

17 Advies Dementie van de Gezondheidsraad, adviesnummer 2002/ 04. 
aantal mensen met fysieke stoornissen of chronische ziekten. Hierdoor wordt de noodzaak van coördinatie en afstemming groter.

Er zijn natuurlijk veel meer veranderingen gaande in de langdurende zorg. In dit kader beperk ik me tot de vier genoemde, omdat ik denk dat die het duidelijkst richting geven aan het denken over de inzet van technologie in de zorg: er is behoefte aan technologie die monitoring en zorg op afstand mogelijk maakt, aan technologie die eigen regie en zelfmanagement van cliënten ondersteunt en aan technologie die complexe zorgprocessen en samenwerking ondersteunt. Bij dat laatste denkt u natuurlijk meteen aan zaken als het electronisch patientendossier, maar het gaat ook om registratie, informatie-uitwisseling, patiëntenlogistiek en dergelijke. Naast deze drie toepassingsgebieden van technologie is er grote druk om technologie in te zetten die de zorg efficiënter maakt, zodat we met minder mensen meer kunnen doen ${ }^{18}$.

\begin{abstract}
Voorbeeld 2: de sensorphone
Door een samenwerkingsverband van Vilans, Vodafone en Maastricht Instruments, onderdeel van de Universiteit Maastricht, is de zogenaamde sensorphone ontwikkeld. Dit is een volledig draadloos monitoringsysteem dat gebruik maakt van een standaard mobiele telefoon voor het overbrengen van gegevens. Het systeem is experimenteel getest bij mensen met overgewicht. Sensoren op het lichaam van de cliënt meten de dagelijkse hoeveelheid beweging en de hartslag. De meetresultaten worden verzameld door een apart kastje dat de meetgegevens op gezette tij den draadloos en automatisch via de mobiele tel efoon naar een beveiligde website stuurt. De gebruiker heeft met zijn mobiele telefoon of computer toegang tot deze website en kan daar een overzicht krijgen van zijn of haar bewegingsactiviteit en andere gegevens. Met een trainer worden doelen voor het bewegen afgesproken en het systeem geeft aan of deze doelen gehaald worden. Op deze manier krijgt de gebruiker heel directe feedback en wordt hij geconfronteerd met zijn eigen gedrag. Dit systeem is ook toepasbaar bij mensen die gewoon actief willen werken aan meer bewegen of aan het houden van een gezond gewicht. In de veldtest bleek het systeem technisch nog enkele onvolkomenheden te hebben, maar het concept is zondermeer veelbelovend ${ }^{19}{ }^{20}$. Met een beetje fantasie zie je de mogelijke doelgroepen zo voor je. Het zal nog enig (door)ontwikkelwerk vergen, maar dat is een kwestie van tijd. Inmiddels zijn vergelijkbare producten op de markt gebracht, onder andere van de firma Mobihealth $\mathrm{BV}^{21}$ en de Personal Activity Monitor (PAM). De PAM geeft feedback via een 'virtuele coach' op de PAM website ${ }^{22}$.
\end{abstract}

\footnotetext{
${ }^{18}$ Goris A en Mutsaers H. Ruimte voor arbeidsbesparende technologie om in 2025 voldoende zorg te kunnen bieden. STG / Health Management Forum, Leiden, 2008.

${ }_{19}$ Arnoldussen E, Childs R, Eschenauer L e.a. Sensorphone. Mobile telephone based wireless patient activity monitoring and telecare system. Vodafone, Maastricht Instruments, Vilans, 2007.

${ }^{20}$ Boer EGM de, Kneppers EM. Sensorphone Obesitas, van idee tot PeeVeeEee. Afstudeerscriptie Bewegingstechnologie, Haagse Hogeschool, 2006.

${ }^{21}$ www. mobihealth.com.

22 www.pam.com.
} 


\section{Innovaties in de zorg}

Innoveren in de zorg is niet eenvoudig. Er wordt heel wat afgeïnnoveerd, maar veel van deze innovaties blij ven steken op lokaal niveau of stranden als de bedenker of trekker vertrekt. Er zijn verschillende soorten innovaties, die elk hun eigen dynamiek kennen. Voor de eenvoud hanteer ik een driedeling.

De eerste soort zijn zorginhoudelijke innovaties; een nieuw medicijn, een nieuwe operatietechniek, een nieuwe therapievorm. Dergelij ke innovaties kennen een redelijk helder beloop: er wordt onderzoek gedaan naar de effectiviteit en later de kosten-effectiviteit, vervolgens wordt hierover gepubliceerd en via nascholingsbijeenkomsten en congressen komen de nieuwe inzichten bij de collega's. Bij bewezen kosten-effectiviteit zal na verloop van tijd deze innovatie zijn weg naar toepassing wel vinden.

Ingewikkelder wordt het bij de tweede soort innovaties: organisatorische innovaties. Voorbeelden hiervan zijn samenwerkingsmodellen rondom de zorg voor mensen na een beroerte, diseasemanagement modellen voor diabeteszorg, en dergelijke. Bij dit soort innovaties moeten professionals en/ of zorgorganisaties op een andere manier met elkaar samen werken, en worden vaak verantwoordelijkheden verlegd van de ene naar een andere professional, bij voorbeeld van een medisch specialist naar een gespecialiseerd verpleegkundige. Implementatie van dergelijke innovaties in de zorg verloopt moeizamer dan die van de eerste soort. Er is veel meer invloed van lokale omstandigheden, individuele karakters van mensen die elkaar wel of niet liggen, enzovoort ${ }^{23}$. En mensen zijn nu eenmaal geneigd vast te houden aan verworven posities en gewoonten. Daar komt bij dat veel zorgorganisaties last hebben van het 'not invented here' syndroom, waardoor dingen die niet uit 'eigen huis' komen moeilijk overgenomen worden. Daarom is het verstandig om dergelij ke innovaties met meerdere zorgaanbieders tegelijk te ontwikkelen. Dat is wel ingewikkelder, maar de kans op implementatie wordt er sterk door vergroot. Een extra hindernis voor implementatie van dit type innovaties is dat het bewijs voor kosten-effectiviteit vaak moeilijker te verkrijgen en ook minder eenduidig is dan bij innovaties van de eerste soort. Effecten liggen vaak op de lange termij $n$ en het kost veel inspanning juist in het begin ${ }^{24}$.

Nog ingewikkelder wordt het bij zorginnovaties waar technologie een belangrijke rol speelt. Dit gaat bijna altijd gepaard met organisatorische veranderingen en veranderingen in de verantwoordelijkheden van professionals, maar er komen nog een paar lastige dimensies bij: er zijn opeens technici en ontwikkelaars nodig, die vaak een heel andere 'taal' spreken en heel anders tegen dingen aankijken, en de inbreng van bedrij ven is noodzakelijk waarbij onvermijdelijk commerciële belangen aan de orde zijn. Dat laatste is niet erg, in tegendeel: het kan een krachtige drijfveer zijn voor verspreiding en implementatie, maar het maakt het wel

\footnotetext{
${ }^{23}$ In haar proefschrift geeft Eijkelberg een overzicht van de factoren die het succes van dergelijke innovaties beïnvloeden [Eij kelberg IM] G. Key factors of change processes in shared care. Proefschrift Maastricht, 2007].

${ }^{24}$ Zie bij voorbeeld: Steuten LM, Lemmens K, Vrijhoef B. Health technology assessment of asthma disease management programs. Curr Opin Allergy Clin Immunol. 2007 J un; 7(3):242-8, of Steuten LM, Vrijhoef B, Merode F van, Wesseling GJ , Spreeuwenberg C. Evaluation of a regional disease management programme for patients with asthma of chronic obstructive pulmonary disease. Int J Qual Health Care 2006; 18(6):429-36.
} 
moeilijker. Volgens mij vormt deze complexiteit een van de redenen waarom er in de langdurende zorg nog maar zo beperkt geïnnoveerd wordt met technologie.

Een centraal punt in de geschetste complexiteit is het verschil in 'taal' en cultuur tussen zorgverleners en technologie-ontwikkelaars. De langdurende zorg heeft nog een sterk ambachtelijk karakter en mensen zijn vaak in de zorg gaan werken om te 'zorgen', wat in hun beleving wringt met gebruik van technologie.

Zorgprofessionals worden door technici vaak afgeschilderd als 'soft' en omgekeerd worden technici door mensen in de zorg vaak als 'nerds' gezien. In de opleiding van zorgprofessionals wordt ook nauwelijks aandacht besteed aan de mogelijkheden van technologie en omgekeerd leren technici niets over de zorg. Het is dus niet vreemd dat beide werelden elkaar niet makkelijk verstaan. Om dit te veranderen moet er iets gebeuren in het onderwijs ${ }^{25}$. Technici en ontwikkelaars moeten een idee krijgen hoe de praktijk van de zorg er uit ziet en omgekeerd moeten zorgprofessionals een beeld krijgen van wat de techniek te bieden heeft. Ik denk dat hieraan in het onderwijs aan zowel zorgprofessionals als technici aandacht besteed moet worden. Dat is de reden waarom ik met twee collega lectoren op het gebied van technologie en zorg een handboek heb samengesteld. Dit draagt de titel "Technologie en langdurende zorg" ${ }^{26}$. Het beschrij ft in 10 hoofdstukken de zorg op een voor leken toegankelijke manier en vervolgens in 16 hoofdstukken een aantal terreinen in de technologie op een voor niet-technici toegankelijke manier. Vervolgens wordt een hele reeks voorbeelden van toepassingen van die technologie ten behoeve van de zorg beschreven. Dit boek verschijnt zeer binnenkort bij uitgeverij Lemma. Met dit boek hopen we de werelden van techniek en zorg in het onderwijs dichter bij elkaar te brengen. Maar er is meer nodig. Het zou zeer te overwegen zijn om, samen met enkele hogescholen en deze universiteit, een masteropleiding technologie in de zorg te ontwikkelen, die mensen uit zowel de zorg als de techniek voorbereidt op een carrière op dit gebied.

Er zijn nog een paar andere problemen met innovatie. Een daarvan heeft te maken met de manier waarop wij in de wereld van het gezondheidsonderzoek hebben geleerd aan te kijken tegen kennisopbouw. Wij baseren ons bij de ontwikkeling van nieuwe aanpakken en dergelijke sterk op systematisch literatuuronderzoek. Wat heeft al bewezen te werken, en wat niet? Die benadering heeft het inzicht in effecten van therapie enorm vooruit gebracht, maar het is ook een benadering die innovatie in de weg staat. Durven we ook eens de dingen op een heel andere manier te doen? Dit is een lastig spanningsveld. Enerzijds moet je natuurlijk voortbouwen op bestaande en beproefde concepten en modellen, maar anderzijds moeten we ook heel nieuwe wegen durven bewandelen. Ik heb het gevoel dat we in het gezondheids(zorg)onderzoek in dit opzicht wat te voorzichtig zijn geworden. De wijze waarop we besluiten over introductie van nieuwe zorgvormen of hulpmiddelen, en dan met name over de vraag of deze door de verzekeraar vergoed mogen worden, versterkt deze voorzichtigheid; iets komt pas voor financiering in aanmerking als de kosten-effectiviteit overtuigend is aangetoond. Daarbij lijkt het alsof de eisen bij technologie nog strenger zijn dan bij andere

\footnotetext{
${ }^{25}$ Zie ook het advies 'Techniek met Zorg' van de Commissie Technologie, Zorg en Opleiding, november 2004.

${ }^{26}$ Hilly Kort, Anneloes Cordia en Luc de Witte. Technologie en langdurende zorg. Lemma uitgeverij, IN DRUK.
} 
interventies. Gevolg is dat het lang duurt voordat innovaties op basis van technologie de praktijk kunnen bereiken, zo lang zelfs dat de technologie soms alweer achterhaald is. Een aanpak die kan helpen om dit proces te versnellen is de door TNO in samenwerking met 0 .a. het voormalig iRv, nu Vilans, ontwikkelde TERTZ: technologie effect rapportage transmurale zorg ${ }^{27}$. Deze methode is een quick scan die helpt om in een vroeg stadium van de ontwikkeling een innovatie te toetsen aan de behoeften en werkwijzen in de zorg. Daarmee kan vooraf de kans op succesvolle innovatie ingeschat worden en kan met zwakke punten rekening gehouden worden.

Ik wil nog een probleem rond innovatie bespreken. Bij veel partijen leeft het tamelijk hardnekkige beeld dat er, als het over technologie gaat, heel veel 'op de plank ligt', klaar voor gebruik, en dat daarvoor geen onderzoek meer nodig is. Het is waar dat er technologisch veel kan, maar het is een misvatting dat dit allemaal kant en klaar in de zorg toegepast kan worden. Een mooi voorbeeld zijn de alarmintercom-systemen (AIS) die gebruikt worden in ADL-clusterwoningen voor mensen met ernstige lichamelijke beperkingen. Recent hebben wij op verzoek van het College voor Zorgverzekeringen een onderzoek gedaan naar de ontwikkelingen op dit terrein. Op dit moment worden voor deze systemen aparte kabels getrokken van de centrale zorgpost naar de betreffende wooneenheden. Een van de vraagstellingen was of de huidige technologie, draadloze breedband toegang tot internet, het aanleggen van dergelijke aparte kabels overbodig zou kunnen maken. Dat zou mogelijk minder kosten met zich mee brengen en in ieder geval veel grotere flexibiliteit betekenen. Ik ga hier niet in op de details van het onderzoek, maar de conclusie van een groep experts was dat de huidige stand van de technologie onvoldoende zekerheid biedt ten opzichte van de nu gebruikte systemen met vaste bekabeling. Met name de zeer hoge eisen die aan de betrouwbaarheid van het systeem gesteld worden zijn met de nieuwe technologie nog niet haalbaar ${ }^{28}$. Dit voorbeeld laat zien dat een algemeen gebruikelijke technologie, het merendeel van de Nederlandse huishoudens heeft een breedband internet verbinding, niet zonder meer in de zorg kan worden toegepast. Dit vergt echt nader onderzoek en gericht ontwikkelwerk.

Om zorginnovaties op basis van technologie succesvol te laten zijn is intensieve samenwerking tussen mensen uit de praktijk van de zorg, technici/ ontwikkelaars en kennisinstellingen van belang. Problemen en knelpunten in de praktijk van de zorg moeten het vertrekpunt zijn, maar professionals in de zorg moeten open staan voor de nieuwe mogelijkheden die technologie biedt. Een belangrijk aandachtspunt is een zekere schaalgrootte: bedrijven zullen alleen commercieel geïnteresseerd zijn als ze de reële verwachting hebben dat het te ontwikkelen product voldoende kans maakt in de markt. Dat betekent dat partijen in de zorg op voorhand bereid moeten zijn om samen aan innovaties te werken. Een ander belangrijk aandachtspunt is het onderzoek dat productontwikkeling moet begeleiden. Heel anders dan bijvoorbeeld in de geneesmiddelenwereld is het bij de ontwikkeling van technologie ten behoeve van de zorg niet gebruikelijk om veel onderzoek te doen.

\footnotetext{
27 Zie voor een samenvatting: Boxsel J van, Schoone M. TERTZ: een technologietoets voor de zorgsector. Health Management Forum 2005, 11: 36-37.

${ }^{28}$ Jacobs O, Leeuw J van der, Willems ChG, Witte LP de. Beoordeling thuiszorgtechnologie: inzicht in nieuwe technieken en consequenties voor financiering van Adl-clusters. Vilans, Utrecht, mei 2008 (in opdracht van CvZ).
} 
Dat is wel van groot belang, en wel op twee manieren: a) funderend onderzoek naar wat de technologie precies moet doen en met welke factoren bij het gebruik rekening gehouden moet worden, en b) onderzoek naar de effecten, zowel beoogd als niet beoogd. Dit is het domein van de kennisinstituten: universiteit, hogeschool, Vilans en andere. Zij hebben de rol om samen met zorgorganisaties, bedrij ven en technologie-ontwikkelaars, begeleidend onderzoek te doen in het proces van ontwikkeling naar implementatie.

Ik pleit voor een hechte samenwerking tussen genoemde partijen - bedrijven, zorgorganisaties en kennisinstituten - bij het ontwikkelen van zorginnovaties met inzet van technologie. "Invented together" moet het beeld worden.

\begin{abstract}
Voorbeeld 3: de introductie van zorgTV
In de thuiszorg is een aantal zorgorganisaties erg actief bij de introductie van zorg op afstand. De brancheorganisatie ActiZ heeft hierop een actief beleid ${ }^{29}$. Bij zorg op afstand gaat het over zorgverlening waarbij de zorgverlener niet fysiek aanwezig is maar waarbij de communicatie via communicatiemiddelen op afstand plaats vindt. Het meest aansprekende voorbeeld hiervan is contact tussen cliënt en zorgverlener via het beeld van een televisie of ander scherm. Via dit beeld kunnen naast zorg tal van diensten aangeboden worden. Het concept is eenvoudig en de technologie in principe ook. Maar het heeft heel wat voeten in aarde om dit te realiseren. De zorgverlener komt in een heel andere rol, die nieuwe vaardigheden vergt. En de organisatie van het zorgproces wordt geheel anders. Ook de cliënt zal moeten leren om via een camera en beeldscherm te communiceren en zich voldoende veilig en 'verzorgd' te voelen. Er wordt volop geëxperimenteerd met deze nieuwe zorgvorm. Over de effecten is nog weinig bekend; die zijn pas goed te beoordelen bij voldoende schaalgrootte. Maar de ervaringen zijn overwegend positief ${ }^{30}{ }^{31}$. Het is heel realistisch te verwachten dat deze vorm van zorg binnen enkele jaren breed toegepast wordt. Momenteel loopt er bij twee thuiszorgorganisaties in Limburg, Proteion Thuiszorg en Orbis, een groot project waarbij ZorgTV op grote schaal geïmplementeerd wordt. Het project wordt begeleid met een (beperkt) onderzoek naar de effecten.
\end{abstract}

\title{
De relatie HBO - WO
}

Ik beloofde $\mathrm{u}$ in te gaan op de relatie tussen de universiteit en het HBO. Ik opereer al een aantal jaren in beide delen van het kennisuniversum en nu ik lector en hoogleraar ben, kan het niet anders dan dat ik hier iets over zeg. Ik heb mij er altijd over verbaasd waarom wij in Nederland zo' $n$ ander stelsel hebben dan in veel buitenlanden. Waarom is de medische opleiding universitair en kan een ergotherapeut of logopedist niet een wetenschappelijke titel halen in het eigen vak? Dat is toch eigenlijk vreemd. Voor de beroepsontwikkeling van paramedische en verpleegkundige disciplines is praktijkgericht onderzoek toch even belangrijk als voor medische disciplines? In ons stelsel zijn HBO en WO gescheiden en vanuit een HBO opleiding doorstromen naar een universiteit is bepaald niet vanzelfsprekend.

${ }^{29}$ ActiZ Programmaplan Zorg op afstand 2007-2010, nr. 08003, I. Borghuis, januari 2008.

30 Thie J. Schermzorg. Zorg op afstand via camera en beeldscherm. Uitgeverij Lemma / Vilans, Den Haag / Utrecht, 2008.

31 Willems CG, Vlieger S de, Vlaskamp F, PijI D van der. Onplanbare zorg in Noord en Midden Limburg. Eindrapport. Hoensbroek, iRv (thans Vilans), 2006. 
Dit vergt een omslachtige en dure omweg, vreemd als je bedenkt dat op dit moment 33\% van de instroom in universitaire master opleidingen bestaat uit HBObachelors. Natuurlijk zijn er niveauverschillen tussen de studenten aan een hogeschool en die aan een universiteit, maar die verschillen zijn ook binnen beide onderwijssoorten groot. Ik heb inmiddels aan de hogeschool Zuyd HBO-scripties gezien die het als afstudeerwerk aan de Universiteit Maastricht goed zouden doen en scripties aan de UM die bij de hogeschool zouden zijn afgekeurd. Dit is natuurlijk niet het gemiddelde beeld, maar beide komen voor. Ik ben van mening dat de doorstroming tussen $\mathrm{HBO}$ en WO voor studenten in beide richtingen veel makkelijker moet en dat universiteiten en hogescholen in de programmering en uitvoering van onderzoek veel meer zouden moeten samenwerken. Daarbij is er natuurlijk een onderscheid in de aard en gerichtheid van het onderzoek dat beide doen: in het HBO staan beroepsontwikkeling en implementeren van wetenschappelijke kennis en inzichten centraal, de universiteit richt zich vooral op theorieontwikkeling en methodologisch complex of baanbrekend onderzoek. Deze typen onderzoek vullen elkaar uitstekend aan en zijn beide nodig om innovaties in de zorg werkelijkheid te maken. Ik hoop vanuit mijn dubbelpositie een bijdrage te kunnen leveren aan het dichter bij elkaar brengen van WO en HBO, met behoud van het eigen karakter van beide. Ik hoop ook mensen vanuit het $\mathrm{HBO}$ de kans te kunnen geven zich als onderzoeker te ontwikkelen op het eigen vakgebied, via een master opleiding gericht op zorginnovatie ${ }^{32}$ en/ of via een promotieonderzoek.

Mijn visie op de relatie WO-HBO wordt in toenemende mate gedeeld door bestuurders in het hoger onderwijs ${ }^{33}$. Ook op de werkvloer merk ik een groot verschil tussen de huidige situatie en die 6 jaar geleden toen ik als lector aan de hogeschool Zuyd ging werken. De bereidheid tot samenwerking vanuit zowel de universiteit Maastricht als de hogeschool Zuyd is duidelijk toegenomen. Dit uit zich onder andere in een toenemend aantal promotieonderzoeken van docenten. Op dit moment werken 12 docenten van de hogeschool aan een promotieonderzoek, waarvan het grootste deel aan de Universiteit Maastricht zal promoveren.

\section{Voorbeeld 4: valpreventie, -predictie en -detectie bij ouderen met een hoog valrisico}

Vallen komt veel voor bij ouderen. De gevolgen zijn groot: heupfracturen en ander letsel, angst om opnieuw te vallen met daardoor angst om naar buiten te gaan, enzovoort. Er wordt niet voor niets zeer veel onderzoek gedaan naar mogelijkheden om vallen te voorkomen, zowel bij thuiswonende ouderen als in de intramurale zorg. Vast staat dat een goede lichamelijke conditie een belangrijke preventieve factor is, naast adequaat gebruik van hulpmiddelen, goed gebruik van medicatie, en nog een hele reeks factoren. Er is een hele reeks aan programma's ontwikkeld, met deze universiteit als een van de koplopers, en er wordt veel onderzoek gedaan. Technologie speelt in de ontwikkelde programma's nauwelijks een rol. Wij werken met een internationale groep onderzoekers aan een integraal

\footnotetext{
32 Aan de universiteit Maastricht bestaat de opleiding 'health services innovation'. Deze opleiding is voor paramedici en verpleegkundigen die een rol willen spelen in zorginnovatie zeer geschikt.

33 Voor een discussie hierover zie 0.a. het jubileumnummer van het tijdschrift voor hoger onderwijs, jaargang 25, nummer 3, 2007 [Noorda S.J. Het hangt ervan af; over de toekomst van hogeschool en universiteit]. [Terpstra en van Braam. Naar een nieuwe agendering voor samenwerking hbo-wo].
} 
technologieconcept voor zelfstandig wonende ouderen, gericht op het voorkomen en voorspellen van vallen en het signaleren en alarmeren als iemand onverhoopt toch valt. Het concept bestaat uit vier onderdelen: a) sensoren die de mate van lichamelijke activiteit meten, zoals in het eerdere voorbeeld van de sensorphone; b) een badkamerweegschaal die de balans bij staan kan meten en deze dagelijks relateert aan het gemiddelde van de voorliggende periode, zodat gesignaleerd wordt als iemand minder stabiel staat; c) intelligente software die op basis van de resultaten feedback en advies geeft aan de oudere en die als het nodig is een signaal stuurt naar een zorgverlener; d) een valsensor met plaatsbepaling die registreert als er toch onverhoopt een val optreedt en dan alarmeert naar een zorgcentrale, met vermelding van de plaats waar de gevallen oudere zich bevindt. De lossen onderdelen van dit systeem zijn in principe beschikbaar. Het gaat er om deze te integreren tot een werkend concept en in te bedden in een zorgprogramma. Want dat is essentieel; een dergelijk systeem heeft alleen zin als het past in een zorgconcept. Het idee is dat het systeem registreert of de cliënt voldoende beweegt, registreert als er iets verandert in de balans, en op basis van deze gegevens adviezen geeft, al dan niet met tussenkomst van een professional op afstand. Het zal nog wel even duren voordat dit systeem verkrijgbaar is, maar het vormt in principe een belangrijke aanvulling op alle andere aanpakken om vallen te voorkomen.

\section{Het belang van verspreiding en implementatie en de rol van niet-universitaire kennisinstituten}

Een manco van de meeste universitaire onderzoekers is dat ze vaak alleen geïnteresseerd zijn in wetenschappelij ke publicaties, en weinig oog hebben voor implementatie en toepassing. Dat is ook waar ze op afgerekend worden, en het is de primaire taak van universiteiten. Prima dus. Voor zorginnovatie is dit echter onvoldoende. Ik sprak al over het belang van het HBO op dit punt: hogescholen kunnen een wezenlijke rol vervullen in het vertalen van resultaten van wetenschappelijk onderzoek naar de praktijk van de zorg. Evidence based practice in niet voor niets een centraal begrip in de gezondheidszorgopleidingen aan de hogeschool Zuyd in Heerlen. Maar voor succesvol implementeren van zorginnovaties en naar het werkveld brengen van kennis is nog meer nodig. Hier zijn de nietuniversitaire kennisinstituten van wezenlijk belang. Voor het terrein van de landurende zorg is dat Vilans, met haar hoofdvestiging in Utrecht en tweede locatie in Hoensbroek ${ }^{34}$. Vilans moet naar mijn overtuiging een hoofdrol spelen in het naar het werkveld brengen van kennis: kennis verzamelen, verrijken, valideren en verspreiden. Ik heb daar wel een kritische kanttekening bij: het moet om gefundeerde kennis gaan, dus om resultaten van kwalitatief goed onderzoek; best practices alleen zijn niet genoeg, 'best' moet ook 'good' zijn.

Vilans en universiteiten en hogescholen zijn voor elkaar heel interessante partijen. De universiteit kan succesvol onderzoek via Vilans en hogescholen 'aan de man' brengen en Vilans heeft universiteiten en hogescholen nodig als bron van gefundeerde kennis dit het verspreiden en implementeren waard is. Het is niet voor niets dat ik ook bij Vilans werk.

\footnotetext{
${ }^{34}$ Zie www.vilans.nl
} 


\section{Voorbeeld 5: het persoonlijk zorgdossier}

Er wordt in Nederland al jaren veel energie en geld gestoken in de ontwikkeling van elektronische patiëntendossiers, aan te sluiten op een landelijke infrastructuur. Die landelijke infrastructuur is er inmiddels. Veel zorgorganisaties zijn bezig met de ontwikkeling van nieuwe of aanpassing van bestaande elektronische patiëntendossiers of zorgdossiers om mee te kunnen in deze beweging. Wat daarbij opvalt is dat deze elektronische dossiers vrijwel nooit toegankelijk zijn voor de cliënt; de nadruk ligt sterk op gegevensuitwisseling tussen professionals en het automatiseren van declaraties richting verzekeraars. Daarmee blijven belangrijke kansen voor eigen regie en zelfmanagement van cliënten liggen. Als reactie hierop zijn er verschillende initiatieven om zogenaamde persoonlijke medische dossiers te ontwikkelen. Deze zijn opgezet vanuit de behoefte van de cliënt en beogen de cliënt te helpen bij het managen van de zorg. J e kunt er eigen gegevens in opslaan, door anderen laten inzien en verzenden, en je kunt er meetgegevens in opslaan en weergeven. Er zijn inmiddels ook een paar dossiers op de markt die zowel voor cliënt als betrokken hulpverleners toegankelijk zijn en die gebruikt kunnen worden voor multidisciplinaire samenwerking en ketenzorg. Dergelijke dossiers zijn vooral relevant voor de zorg voor mensen met een chronische ziekte. Al langer bestaande voorbeelden zijn van Medlook (SOS gegevens op internet en informatie over behandelingen en medicatie), de Health Buddy (monitoring van gezondheid door dagelijks enkele vragen te beantwoorden) en het persoonlijk ervaringendossier van de CG-Raad en TNO (niet meer operationeel). Recent heeft ook Google zich op dit terrein gericht met de introductie van Google Health, maar ook Microsoft en IBM hebben persoonlijke zorgdossiers (via Second Life en Health Vault). Deze ontwikkeling is een antwoord op wat de zorgorganisaties massaal laten liggen door zich alleen op de professional te richten. Voor de zorg voor mensen met een chronische ziekte is de ontwikkeling van multidisciplinaire dossiers waar ook de cliënt in kan werken zeer kansrijk. Via dergelijke dossiers kan de communicatie en af stemming tussen professionals geregeld worden: ze maken gebruik van dezelfde gegevens en kunnen direct op elkaar en op de informatie van de cliënt reageren. Ook bieden ze de mogelijkheid om informatie en educatiemateriaal voor de cliënt beschikbaar te maken, gekoppeld aan b.v. bepaalde resultaten van onderzoek. De ontwikkeling van deze toepassingen is technisch mogelijk, er zijn al voorbeelden op de markt ${ }^{35}$, maar om ze optimaal in te zetten is nader onderzoek nodig naar de precieze behoeften van cliënten en betrokken professionals en naar de effecten. Ook zijn er nog belangrijke vragen met betrekking tot de privacy en de beveiliging van de gegevens.

\section{Plannen voor de toekomst}

35 Bijvoorbeeld Caresharing van de firma Palmade Europe BV: zie www.caresharing.eu. 
Ik kom nu toe aan mijn plannen voor de toekomst. Wat ga ik proberen te realiseren? Dat kan ik langs drie lijnen schetsen.

De eerste lijn is die van de inhoud. Toen ik zojuist een aantal trends in de langdurende zorg besprak noemde ik al vier belangrijke gebieden waar technologie een rol kan spelen: zorg op afstand, ondersteuning van zelfmanagement van cliënten, ondersteuning van complexe zorgprocessen en vergroten van efficiëntie van het professionele handelen. Dit zijn de centrale thema's waarop het onderzoek de komende jaren zich zal richten. De centrale vraag is hoe technologie optimaal kan worden ingezet in de praktijk van de zorg om een bijdrage te leveren aan deze vier doelen. Het zal gaan om onderzoek naar gebruikservaringen en bruikbaarheid, onderzoek naar effecten en kosten-effectiviteit en onderzoek naar factoren die van belang zijn voor de implementatie van technologie. Er is geen principiële beperking ten aanzien van de technologie die ingezet wordt. Wel is er speciale aandacht voor het terrein van de robotica en het terrein van de draadloze telezorg. Van beide gaf ik een voorbeeld.

De tweede lijn om mijn plannen te schetsen betreft de samenwerking tussen kennisinstellingen onderling en met de zorgorganisaties en bedrij ven in deze regio. Ik hoop dat er een regionaal innovatieprogramma 'technologie in de langdurende zorg' tot stand komt, waarin de Universiteit Maastricht, de hogeschool Zuyd en Vilans samen werken aan een gericht programma, ontwikkeld met en mede door de zorgorganisaties in de regio en bedrij ven die willen investeren in technologie in de zorg. Belangrij ke stappen in die richting zijn gezet:

a) Er is een samenwerkingsovereenkomst tussen de UM, de hogeschool en Vilans om zo'n programma te ontwikkelen;

b) Er is een groot initiatief van 8 zorgaanbieders, het Arcus College en de hogeschool Zuyd om te komen tot de zogenaamde Zorgacademie Parkstad. In die context wordt gewerkt aan een zorginnovatiecentrum, een fysieke plek waar de partijen waar ik het over heb samen aan innovaties kunnen werken;

c) Vanuit de hogeschool Zuyd werken we aan een project waarin we samen met 14 bedrijven en 6 organisaties in de ouderenzorg een regionaal innovatieprogramma 'technologie in de ouderenzorg' ontwikkelen en uitvoeren. Dit project vormt voor mij de opmaat voor wat er inhoudelijk moet komen in deze regio: een zorginnovatieprogramma dat wetenschappelijke output oplevert, dat zinvolle en effectieve innovaties oplevert die breed geïmplementeerd worden, dat een goede basis biedt voor studenten van zowel de universiteit als de hogeschool om zich te ontwikkelen tot innovatieve en reflectieve professionals, en dat goede onderzoekers trekt die zich op dit gebied willen toeleggen.

d) Vanuit de Universiteit Maastricht wordt gewerkt aan de ontwikkeling van het Academisch Centrum Zorginnovatie Ouderenzorg, kortweg ACZIO. Het te ontwikkelen onderzoek op het terrein van technologie en zorg kan hier een goede inbedding vinden.

Ik denk dat de ontwikkeling van zo' $n$ regionaal innovatieprogramma mogelijk is in deze regio en ik denk dat het moet. Het kan ook bijdragen aan de profilering van deze regio.

De derde lijn om mijn plannen te schetsen is die van de resultaten. Voor vandaag zijn de wetenschappelijke resultaten het meest van belang. Mijn ambitie is dat er de komende vijf jaar tenminste vier mensen promoveren op dit terrein en dat er tenminste 20 wetenschappelijke publicaties verschij nen van onderzoekers in het te 
ontwikkelen programma. De andere resultaten heb ik al genoemd: bruikbare en te implementeren zorginnovaties die bij dragen aan de grote uitdagingen in de langdurende zorg.

\section{Tot slot}

Dames en heren, mijn spreektijd is bijna voorbij. Ik hoop dat ik u een helder beeld heb gegeven van het hoe en waarom van deze leerstoel, en van mijn plannen voor de naaste toekomst. Ik heb u geschetst waar ik denk dat de belangrij kste behoeften en kansen liggen voor de inzet van technologie in de langdurende zorg, en ik heb een aantal voorbeelden daarvan gegeven. Ik hoop dat u dit als stimulerend ervaart. Het gaat om een enorm uitdagend terrein dat potentieel van grote invloed is op hoe de zorg zich in de komende decennia zal ontwikkelen.

De laatste minuten wil ik besteden aan het bedanken van de mensen die het mij mogelijk hebben gemaakt hier vandaag deze rede te houden. Dat zijn er vele: mijn ouders, het gezin waarin ik ben opgegroeid, de mensen met wie ik gestudeerd heb, de zeer vele collega's waar ik mee samenwerk of heb samengewerkt, mijn begeleiders in de eerste jaren van mij $n$ leven als onderzoeker, financiers en opdrachtgevers waar ik voor heb mogen werken, mij $n$ directe naasten, enzovoort. Door hun stimulans, kritiek, collegialiteit, wijze lessen, samenwerking, discussies, liefde en wat al niet meer zij, heb ik mij kunnen ontwikkelen tot wie ik ben. Daar ben ik erg dankbaar voor. Ik heb altijd met heel veel plezier en enthousiasme gewerkt en hoop dat nog lang te doen.

Het is ondoenlijk om iedereen bij naam te noemen, maar mijn vrouw Charlotte noem ik wel. Haar geloof in mij en haar steun om te doen wat ik denk dat goed is geven me de energie om ideeën te realiseren. Tegelijk zorgt zij voor de balans tussen werk en de andere leuke dingen in het leven. Hoewel de omstandigheden niet altijd makkelijk zijn genieten wij daar intens van. Dat heb ik van haar geleerd.

Ik vind het ontzettend leuk om, precies 25 jaar nadat ik aan deze universiteit afstudeerde als arts, nu invulling te mogen geven aan mijn nieuwe rol als hoogleraar. Als ik hier met hetzelfde plezier aan kan werken als het plezier waarmee ik studeerde, dan wacht mij een fantastische tijd.

Ik heb gezegd. 